\title{
PARACOCCIDIOIDOMYCOSIS IN ORGAN TRANSPLANT RECIPIENT: CASE REPORT
}

\author{
Alexandre Prehn ZAVASCKI(1), João Carlos BIENARDT(2) \& Luiz Carlos SEVERO(3)
}

\begin{abstract}
SUMMARY
Paracoccidioidomycosis is a common disease in Latin America but it is rare in organ transplant recipient patients. We report on a case of such mycosis in a renal transplant recipient. The patient presented with a large lung cavity on the left lower lobe, a rare radiological presentation of paracoccidioidomycosis. Unusual clinical and radiological manifestations of Paracoccidioides brasiliensis infection can occur in immunocompromised patients.
\end{abstract}

KEYWORDS: Paracoccidioidomycosis; Paracoccidioides brasiliensis; Organ transplant; Radiography.

\section{INTRODUCTION}

Fungi account for $5 \%$ of all infections in renal transplant recipients. Both epidemiological exposure and the state of immunosuppression determine the type of systemic fungal infection. Candida and Aspergillus species are the most frequently reported fungal pathogens causing infection following renal transplantation. Infections due to geographically limited endemic fungi are not frequent ${ }^{4}$.

Paracoccidioidomycosis (PCM) is a commonly found disease in Latin America residents. However, such mycosis is rare in organ transplant recipient patients. There are only two cases reported in the literature until now that present such mycosis complicating the transplantation of solid organs ${ }^{6,7}$. The aim of this report was to describe another case of PCM in a renal transplant recipient with an unusual radiological presentation of the lung lesions.

\section{CASE REPORT}

The patient was a 43-year-old man who received a cadaveric renal transplantation 14 years ago for end-stage renal failure due to chronic reflux nephropathy. He presented a 2-month history of fever, asthenia, anorexia, weight loss and a dry cough followed by the production of mucopurulent sputum. He was taking azathioprine $100 \mathrm{mg} / \mathrm{day}$, cyclosporine $100 \mathrm{mg} /$ day, and prednisone $5 \mathrm{mg} /$ day. He was not receiving prophylaxis for Pneumocystis. He had no other medical condition. The patient was born in the city of Nova Bréscia (an area where the infection by Paracoccidioides brasiliensis was known to be endemic), where he lived until 17 years of age. At physical examination, he had normal vital signs, a cachectic appearance, mucosal pallor, and seven skin lesions on different sites. Five of them were hyperkeratotic papules and were located on scalp, forehead, right mucocutaneous transition of the nose, right inferior border of the lips and anterior face of the right forearm. Two crusting lesions were located on the right thigh and on the left lumbar region each one. The remaining physical examination was unremarkable. Laboratory studies revealed a normocytic anemia (hemoglobin $7.8 \mathrm{~g} /$ $\mathrm{dL})$, a slightly elevated leukocyte count $(16,400$ cells $/ \mu \mathrm{L})$ with a normal differential count and a high erythrocyte sedimentation rate $(124 \mathrm{~mm} /$ hour). Creatinine level was $0.7 \mathrm{mg} / \mathrm{dL}$ and electrolytes levels were normal. Posteroanterior (Fig. 1) and lateral (Fig. 2) chest roentgenograms revealed opacities and a thick-walled cavity containing a prominent air-fluid level projecting into the superior segment of the left lower lobe. Thorax CT scanning (Fig. 3) revealed multiple sharp circumscribed nodules randomly distributed throughout both lungs, ranging from 5 to $15 \mathrm{~mm}$ diameters. Left lower lobe contained a poorly defined mass with a large cavity. The cavity had a thick, irregular wall and a prominent air-fluid level. Skin lesion biopsy was performed. The histological examination of the cutaneous lesion showed mixed suppurative and granulomatous inflammation, giant cells, pseudoepitheliomatous hyperplasia and numerous multiple $P$. brasiliensis budding cells on Grocott's stained skin sections. The same fungal elements were also found by direct examination of the sputum prepared in potassium hydroxide. Many smeared sputum examinations for acid-fast bacilli were negatives. Immunodiffusion test revealed two precipitin bands against paracoccidioidin.

Treatment with amphotericin B $(1 \mathrm{mg} / \mathrm{kg} /$ day $)$ promoted the resolution of the fever and an improvement of the general health at the $7^{\text {th }}$ day, when this drug was stopped and oral itraconazole $200 \mathrm{mg} /$ day was initiated. After seven days, the patient was discharged home. By the 6-month follow-up period he remained asymptomatic and presented an almost complete resolution of lung lesions. 


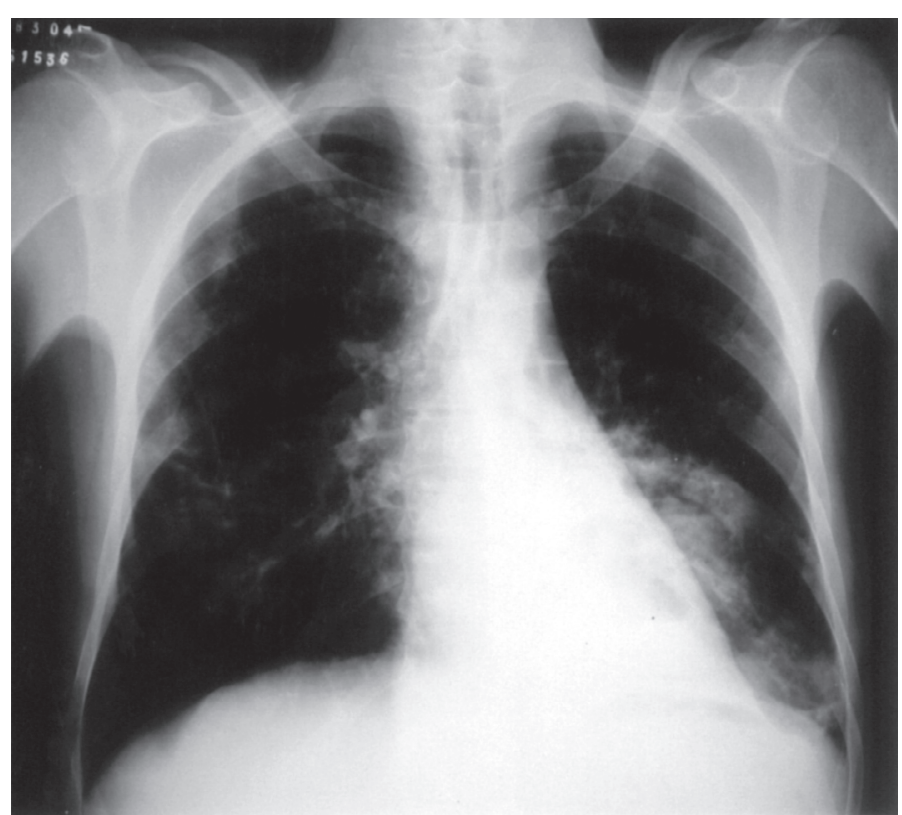

Fig. 1 - Posteroanterior chest radiograph reveals opacities throughout both lungs and area of consolidation in the left lower lobe.

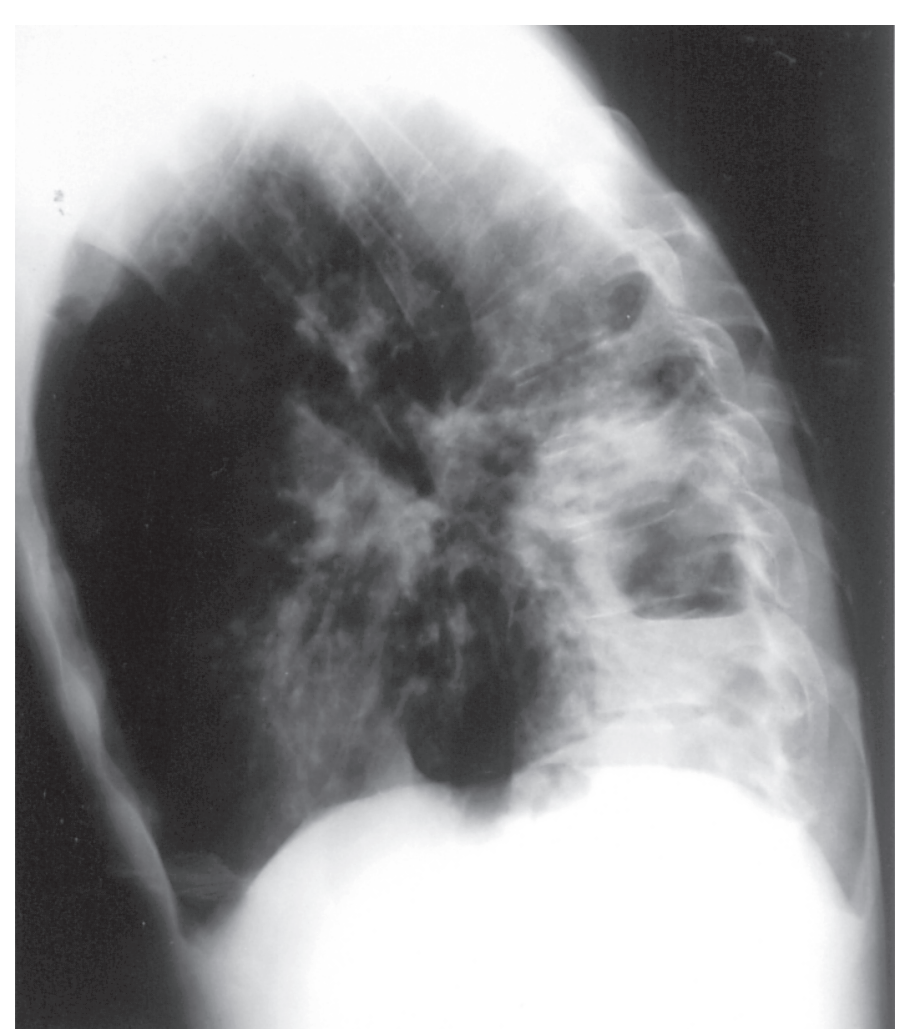

Fig. 2 - CT scan of the chest showing a large cavity with air-fluid level in the left lower lobe and multiple sharp circumscribed nodules throughout both lungs.

\section{DISCUSSION}

PCM is the most common endemic mycosis in Latin America. The

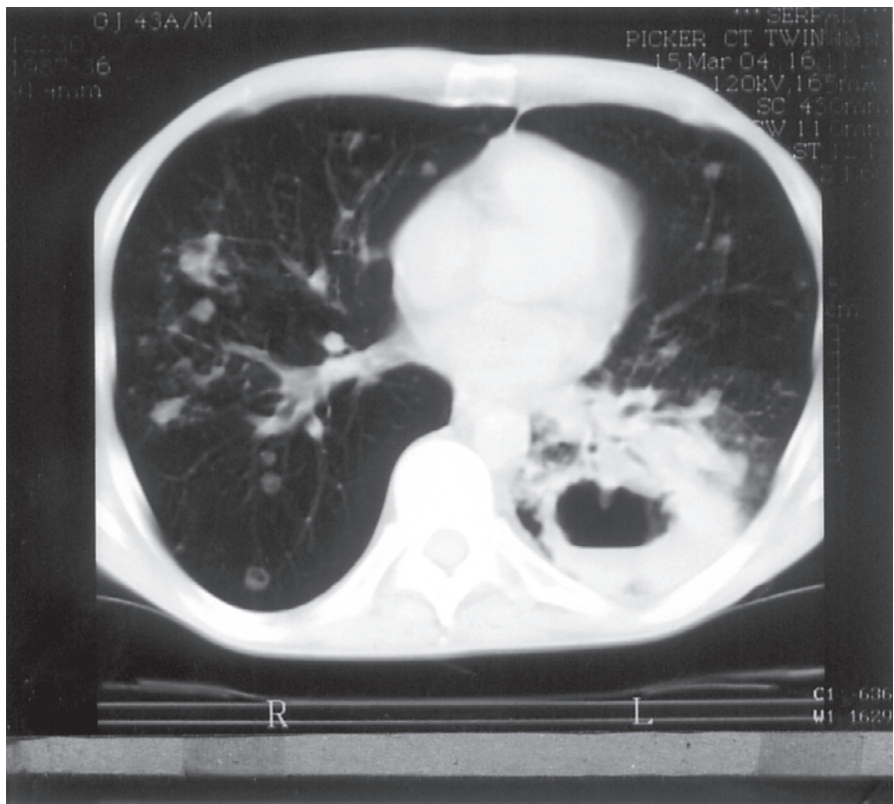

Fig. 3 - Lateral chest radiograph shows thick-walled fluid-containing cavity in the superior segment of the left lower lobe.

etiologic agent, $P$. brasiliensis, is a thermally dimorphic fungus that usually affects previously healthy adults. It primarily involves the lungs and then it disseminates into other organs ${ }^{1}$.

PCM in solid organ transplant patients was firstly reported in $1984^{7}$. Since then, just another case was reported ${ }^{6}$. The present case is the third one reported in the literature. In these previous reports, mean time to fungal infections onset after transplantation was 11 years. Therefore, PCM and blastomycosis, the two least common of the endemic mycoses to affect the transplant patient, differs from coccidioidomycosis and histoplasmosis that are observed in the immediate posttransplant period ${ }^{5}$. The clinical presentation of the first case was similar to other cases of the mycosis in non-immunosuppressed patients ${ }^{7}$. SHIKANAI-YASUDA et al. ${ }^{6}$ reported a case with severe pulmonary infection. In our report, clinical manifestations of the disease were similar to nonimmunosuppressed patients infections. However our patient presented a quite unusual radiological finding.

A variety of chest radiographic findings are encountered in PCM but none of them is pathognomonic. The most common is the mixed interstitial and alveolar infiltrates diffusely distributed throughout both lungs. Cavities are not frequent and, when present, are small, single or multiple, located around central areas of the lungs ${ }^{3}$. To our knowledge, the presence of a large lung cavity having an air-fluid interface has never been shown in PCM, and this is the first case with such radiological presentation reported in the literature.

The epidemiological circumstances of our case bear mention. The primary infection possibly occurred before the 17 years of age when he was still working on soil-related activities in an endemic region (northern of the State of Rio Grande do Sul). For such reason, this case illustrates the reactivation of a quiescent lesion with a latent period of at least 26 years. 
As AIDS patients, PCM scarcity in renal transplant recipients might be explained by routine use of trimethoprim-sulfamethoxazole as a primary prophylaxis for Pneumocystis pneumonia, which is also effective against $P$. brasiliensi ${ }^{2}$. However, $P$. brasiliensis has been increasingly reported as an opportunistic pathogen in immunosuppressed patients ${ }^{1}$ and it is a possible cause of fungal infection in organ-transplant recipients from endemic areas. Clinicians and radiologists should be aware of unusual clinical and radiological manifestations of $P$. brasiliensis infection when evaluating immunocompromised patients from Latin America showing lung and skin lesions, particularly when they fail to identify acid-fast bacilli.

\section{RESUMO}

\section{Paracoccidioidomicose em transplante de órgão: relato de caso}

Paracoccidioidomicose é doença comum na América Latina mas é rara em pacientes transplantados. Relatamos um caso desta micose em um receptor de transplante renal. $\mathrm{O}$ paciente apresentou grande cavidade no lobo inferior esquerdo do pulmão, uma rara apresentação radiológica da paracoccidioidomicose. Manifestações clínicas e radiológicas inusitadas da infecção por Paracoccidioides brasiliensis podem ocorrer em pacientes imunocomprometidos.

\section{REFERENCES}

1. BRUMMER, E.; CASTANEDA, E. \& RESTREPO, A. - Paracoccidioidomycosis: an update. Clin. Microbiol. Rev., 6: 89-117, 1993.

2. GOLDANI, L.Z. \& SUGAR, A.M. - Paracoccidioidomycosis and AIDS: an overview. Clin. infect. Dis., 21: 1275-1281, 1995.

3. MAGALHÃES, A.E.A. \& GUERRINI, R. - Roentgenographic patterns of chest lesions. The use of computerized tomography in paracoccidioidomycosis. In: FRANCO, M.; LACAZ, C.S.; RESTREPO-MORENO, A. \& DEL NEGRO, G., ed. Paracoccidioidomycosis. Boca Raton, CRC Press, 1994. p. 281-288.

4. PATEL, R. \& PAYA, C.V. - Infections in solid-organ transplant recipients. Clin. Microbiol. Rev., 10: 86-124, 1997.

5. SERODY, J.S.; MILL, M.R.; DETTERBECK, F.C. et al. - Blastomycosis in transplant recipients: report of a case and review. Clin. infect. Dis., 16: 54-58, 1993.

6. SHIKANAI-YASUDA, M.A.; DUARTE, M.I.S.; NUNES, D.F. et al. Paracoccidioidomycosis in a renal transplant recipient. J. med. vet. Mycol., 33: 411414, 1995.

7. SUGAR, A.M.; RESTREPO, A. \& STEVENS, D.A. - Paracoccidioidomycosis in the immunosuppressed host: report of a case and review of the literature. Amer. Rev. resp. Dis., 129: 340-342, 1984.

Received: 1 July 2004

Accepted: 19 August 2004 